\title{
The Effectiveness of a Suggested Program Based on Concept Maps in Developing Some Contemporary Design Concepts and Skills among 2nd Grade Preparatory School Students
}

\section{Heba Salah Ali Shaarawi}

An Expert Teacher of Art Education,

Tahnasha Joint Secondary School, El Minia, Egypt.

Abstract:

7 he current research aimed at identifying the effectiveness of a suggested program based on

1 concept maps in developing contemporary design concepts and skills among 2 nd grade preparatory school students. To achieve the research objectives the researcher prepared the following tools: a teachers' guide, working sheets, a test to measure the contemporary design concepts, an observation card to measure contemporary design skills). The researcher utilized the semi-experimental research methodology to a sample consisted of (126) students who were divided into two groups: a control group of (64) students who were taught the unit traditionally, and an experimental group of (62) students who were taught the same unit using the suggested program based on concept maps. Results revealed the effectiveness of the suggested program based on concept maps in developing contemporary design concepts and skills among 2nd grade preparatory school students. In addition, the research recommended using the suggested program based on concept maps in art teaching.

Keywords: A suggested program based on concept maps; contemporary design concepts; contemporary design skills.

\section{Introduction:}

Contemporary art education serves as a means of restoring the human being to his humanity, through developing concepts, sensory perceptions , and imagination, in addition to acquiring learners' critical skills to analyze reality so as to rebuild and modify it 
through art learning and teaching. That the artistic process is no longer abstract skills of science, knowledge ,and appreciation, which influences and achieves its constructive values for using artistic elements that have a philosophical significance and dimension for revealing artistic values and concepts (Ishaq 2005, 16).

In contemporary art education, new strategies are presented to teach the basic concepts of artistic work as elements, foundations, techniques, and values for learners in a way starting from the general to specific, graded according to their cognitive knowledge. One of the most appropriate strategies for teaching basic contemporary design concepts of the artistic work in a simplified way is concept maps through organizing them in a hierarchical form that includes the concepts included in the topics, and the relationships that link them with the aim of providing a kind of meaningful learning.

Because of the significant role that concept maps play in achieving a kind of meaningful learning and improving the quality of the learning process, some studies and researches that were concerned with concept maps as a teaching strategy were conducted. Yahya (2012) revealed the effectiveness of the concept mapping strategy in enhancing the educational achievement of sixth-graders basic education students. Abdul-Moneim (2015) demonstrated the effectiveness of using concept mapping strategy in the skill level of basic education students, in addition to Al-Kudam's (2018) study which indicated the effectiveness of using concept mapping strategy in developing written expression skills among female Arabic language students speaking other languages in Saudi Arabia. 
Accordingly, based on what is presented in reviewing literature and related studies, it became clear that the concept maps strategy plays a significant role in teaching. In spite of this, there is a scarcity of researches that dealt with the use of concept maps in art education-( according to the researcher's knowledge). Therefore, the current research sought to investigate the effectiveness of using concept maps in teaching contemporary design concepts and skills within art education.

\section{Research Problem}

From the researcher work as an art teacher at Minia Governorate, Egypt and through conducting a diagnostic test to identify the level of artistic skills among preparatory school students, it was clear that those students suffer from low artistic skills. In the light of what was mentioned above and according to the research limitations, the current research problem was crystallized in answering the following main question:

What is the effectiveness of the suggested program based on concept maps in developing contemporary design concepts and skills among 2nd grade preparatory school students?

\section{Research Objectives}

The current research aimed at the following:

- identifying the effectiveness of the suggested program based on concept maps in developing contemporary design concepts among 2nd grade preparatory school students.

- identifying the effectiveness of the suggested program based on concept maps in developing contemporary design skills among 2nd grade preparatory school students. 


\section{Research Significance}

The significance of the current research is clear as follows:

- The current research reflects a substantive response to what educators advocate nowadays to cope up with the modern educational trends in teaching and experimenting with various teaching strategies that may lead to positive results in the educational process.

- Providing a teachers' guide to clarify how to utilize concept maps in teaching art education to preparatory school students.

- Presenting student worksheets that would be used during the teaching of art education using concept maps.

- Providing a test to measure the contemporary design concepts presented to 2nd grade preparatory school students.

- Providing an observation card to measure contempor -ary design skills.

\section{Research Limitations}

The current research was limited to the following:

- The research was conducted to a group of 2 nd grade preparatory school students, Tahnsha Joint Preparatory School, Minia Educational Administration, in the academic year 2018-2019.

- The current research was limited to teaching the first unit entitled (Basics in Art), presented in the first semester to second year preparatory school students.

\section{Definition of Terms}

\section{Effectiveness:}

The researcher defined effectiveness procedurally in the current research as the change of the 2 nd grade 
preparatory school students' performance (the research group) after applying the suggested program which was based on using concept maps in contemporary art design concepts and skills, which was evident through the differences between the means of scores obtained in the post-application of the achievement test and observation sheet. It was measured through the effect size equation.

\section{Concept Maps:}

The researcher defined concept maps procedurally in the current research as schematic diagrams of the design course in the form of a hierarchical organization of a set of concepts, generalizations and words that link them. That the most general and comprehensive concepts are placed at the top of the map followed by less general , and comprehensive concepts and then more specific concepts at the base.

\section{The suggested program based on concept maps:}

The proposed program, based on concept maps, was defined as a set of sequential procedures in the form of a hierarchical organization of concepts and words that link them, where the most general and comprehensive concepts are placed at the top of the map followed by less general, and comprehensive concepts and then more specific concepts at the base.

\section{Contemporary Design Concepts:}

The researcher defined contemporary design concepts procedurally in the current research as the basic elements in formulating the artistic work; they were evident by the grades in the artistic concepts test prepared for this purpose.

\section{Contemporary Design Skills:}

The researcher defined contemporary design skills procedurally in the current research as the individual's 
ability to obtain mastery to make work easier for the owner to perform it in the least time and effort, and it is inferred through observation sheet prepared for this purpose.

\section{Research Procedures}

The current research went on through the following procedures: preparing a test for contemporary design concepts, preparing an observation sheet for artistic skills, preparing a suggested program based on concept maps.

\section{Research Sample}

The research sample was chosen from the 2nd year preparatory school students on 26/9/2018, who were enrolled in Tahnasha Preparatory School at Minia Educational Administration, Egypt. It consisted of 126 students and they were divided into two groups:

- The control group: It consisted of two classes with 64 students, who were taught through the traditional teaching methodology.

- The experimental group: it consisted of two classes with 62 students, who were taught according to the suggested program based on concept maps.

After selecting the research sample, the researcher controlled the variables that might affect the results of the research, in order to ensure the equality of the two groups. The following is the set of variables that were set:

- Age: The 2nd year prep. school students were 13 years old.

- The Instructor: The researcher taught the experimental group students and another fellow teacher in the same school who holds the same qualification- a Bachelor of Science and Education-, 
and with the same period of experience, which is approximately 20 years, taught the control group students.

- Previous Achievement Level: To ensure the equivalence of the previous achievement, the concept test (research tool) was applied to students of both groups before teaching. Table (1) shows the significance of the differences between the students' means of the scores in the control and experimental groups in the pre-application of the concept test as follows:

Table (1): The Significance of the Differences between the Students' Means of the Scores in the Control and Experimental

Groups in the Pre-application of the Contemporary Design Concepts Test

\begin{tabular}{|l|l|l|l|l|l|}
\hline Group & N & Mean & SD & t-value & Significance of t-value \\
\hline The Control Group & 64 & 3.56 & 0.97 & & \\
\cline { 1 - 4 } The Experimental Group & 62 & 3.56 & 1.1 & 0.54 & Not significant \\
\hline
\end{tabular}

Table (1) clarified that there were no statistically significant differences between means of scores obtained by students in the control and experimental groups in the pre-application of the contemporary design concepts test. This reflected the equivalence of the two groups before teaching the suggested program.

- Previous Skills Level: To ensure equivalence in terms of the previous skill, an observation card (research tool) was applied to students of both groups before teaching. Table (2) indicated the significance of the difference between the mean scores of students in the control and experimental groups in the preapplication of the observation card. 
Table (2): The significance of the Difference between the Students' Mean of the Scores in the Control and Experimental Groups in the Pre-application of the Observation Sheet

\begin{tabular}{|l|l|l|l|l|l|}
\hline Group & N & Mean & SD & t-value & Significance of t-value \\
\hline The Control Group & 64 & 7.7 & 1.94 & & \multirow{2}{*}{ Not significant } \\
\cline { 1 - 5 } TheExperimental Group & 62 & 7.39 & 1.63 & 0.3 & N.3 \\
\hline
\end{tabular}

Table (2) revealed that there were no statistically significant differences between means of scores obtained by students in the control and experimental groups in the pre-application of the contemporary design skills observation sheet. This reflected the equivalence of the two groups before teaching the suggested program.

- Time allocated for teaching: The current research was committed to the time allocated to teaching art education to second-year preparatory school students, which were (9) periods at the rate of (2) lessons per week, and the teaching process ended $4 / 12 / 2018$, where the concepts test and observation sheet were applied to students of both groups.

\section{Research Results}

The effectiveness of the suggested program based on concept maps in developing contemporary design concepts among 2 nd year preparatory school students.

To verify the first hypothesis stating that" there was statistically significant differences between means of scores obtained by the control group (instructed by the traditional teaching methods) and the experimental group ( taught through the suggested program which was based on concept maps) in the post-application of the contemporary design concepts test in favor of the experimental group", the researcher utilized the 
Independent-Samples $t$ Test through SPSS to calculate the significance of the differences between the means of scores of both the experimental and control group in the post- application of the concept test. Moreover, the researcher calculated the effect size "r".

Table (3): The Significance of Differences between the Students' Means of the Scores in the Control and the Experimental Group in the Post-application of Concepts Test in Favor of the Experimental Group and the Effect Size

\begin{tabular}{|c|c|c|c|c|c|c|c|}
\hline Group & $\mathbf{N}$ & Mean & SD & "t" & $\begin{array}{c}\mathbf{t} \\
\text { Significance }\end{array}$ & $\begin{array}{c}\text { Effect } \\
\text { Size } \\
\text { "r" }\end{array}$ & $\begin{array}{c}\text { Effect } \\
\text { Significance }\end{array}$ \\
\hline The Control Group & 64 & 15.02 & 7.75 & & Significant & & \\
\hline $\begin{array}{c}\text { The experimental } \\
\text { Group }\end{array}$ & 62 & 29.65 & 7.07 & 10.97 & $\begin{array}{c}\text { at } \\
0.01 \text { Level }\end{array}$ & 0.7 & Large \\
\hline
\end{tabular}

Table (3) indicated that there were statistically significant differences between means of scores obtained by the control group(taught by the traditional teaching method) and the experimental group (taught according to the suggested program based on using concept maps) in the post-application of the contemporary design concepts tests in favor of the experimental group students. Furthermore, the effect size 0.70 is large. Thus, the first hypothesis of the research was validated.

The effectiveness of the suggested program based on concept maps in developing contemporary design skills among 2nd year preparatory school students.

To verify the second hypothesis stating that" There was a statistically significant differences between means of scores obtained by the control group ( taught by the traditional teaching methods) and the experimental group( taught through the suggested program which was based on concept maps) in the post-application of the contemporary design skills 
observation sheet in favor of the experimental group", the researcher utilized the Independent-Samples t Test through SPSS to calculate the significance of the differences between the means of scores of both the experimental and control group in the post- application of the skills observation sheet. Moreover, the researcher calculated the effect size "r".

Table (4): The Significance of Differences between the Students' Means of the Scores in the Control and the Experimental Group in the Post-application of Observation Card and the Effect Size

\begin{tabular}{|c|c|c|c|c|c|c|c|}
\hline Group & $\mathbf{N}$ & Mean & SD & "t" & $\begin{array}{c}\mathbf{t} \\
\text { Significance }\end{array}$ & $\begin{array}{c}\text { Effect } \\
\text { Size } \\
\text { "r" }\end{array}$ & $\begin{array}{c}\text { Effect } \\
\text { Significance }\end{array}$ \\
\hline The Control Group & 64 & 6.3 & 2.83 & & & & \\
\hline $\begin{array}{c}\text { The experimental } \\
\text { Group }\end{array}$ & 62 & 19.7 & 4.77 & 10.97 & 0.01 Level & 0.87 & Large \\
\hline
\end{tabular}

Table(4) indicates that there are statistically significant differences between means of scores obtained by the control group (taught by the traditional teaching method) and the experimental group (taught according to the suggested program based on using concept maps) in the post-application of the contemporary design skills observation sheet in favor of the experimental group students. Furthermore, the effect size 0.87 is large. Thus, the second hypothesis of the research was validated.

\section{Recommendations}

In the light of the current research results, the following recommendations can be presented:

1. Utilizing the suggested program based on using concept maps presented in the current research as it approved its effectiveness in teaching as it enhances 
achievement, skill, product quality and achievement motivation.

2. Training the art education college students and teachers to use concept maps in teaching art through teaching methods course and during their practical training.

\section{Suggested Research}

In the light of the research results, the following research can be proposed:

- Conducting the current study on pupils of different educational levels.

- Investigating the effectiveness of using concept maps in developing critical and creative thinking skills.

- Comparing between the effect of using concept maps on teaching and some other recent educational trends in students' skills achievement and motivation for achievement.

\section{References}

- Abdel Aziz,H. (2008). The Effectiveness of the Achievement Teams and Learning Together strategy $A$ in Gaining Prep Preparatory 1 pupils artistic concepts and the trend towards cooperative work. Journal of Research in Education and Psychology, 3(21).

- Abdel-Latif,H. (2011). The effectiveness of cooperative learning strategy in developing innovative design skills and some social skills in art education for students in the second cycle of basic education. Master Thesis, Institute of Educational Studies, Cairo University.

- Abdel-Moneim,M. (2015). The effect of an educational program using the concept maps strategy on the skill level performance of 
students of the Education Division. The Scientific Journal of Physical Education and Sports Science, Faculty of Physical Education, Helwan University, 74, 241-368.

- Al-Kadum,M. (2018). The effectiveness of conceptual mapping strategy in developing written expression skills among female students of Arabic language speaking others in the Kingdom of Saudi Arabia. Journal of Education, Al-Azhar University, 180 (2)

- Ahmed,M. (2011). The Effectiveness of a proposed training program for developing artistic skills in the field of manual printing for mentally handicapped people who can learn. Master Thesis, Faculty of Art Education, Helwan University.

- Al-Lakany,A. (2003). The curriculum (foundations - components regulations). Cairo, the world of books.

- Al-Lakany,A. , Al-Jamal,A.(2003). A Dictionary of Cognitive Educational Terms in Curricula and Teaching Methods. $3^{\text {rd }}$ edition, Cairo, The World of Books.

- Al-Shalabi,I.(2010). The effect of using the conceptual map strategy on the achievement of the 9th grade students the scientific concepts in biology, their achievement motivation and their ability to creative thinking. Journal of Educational and Psychological Sciences, 11,(2).

- Awaid,R. (2012). The effectiveness of using the concept maps strategy in developing the concept of color among fourth-grade primary students. Master Thesis, College of Education, University of Madina, Saudi Arabia.

- August.Melek,G.(2004). Door to the future, Understanding of Ancient Seljuk Colleges. Journal of Art and Design Education, 23(1), 63-72.

- Edmondson.K(1995). Concept mapping for the Development of Medical CURRICULA. Journal of Research in Science Teaching,32(7).

- El-Ghattami,A. (2010). Constructing concept maps to analyze artistic work and its role in developing artistic appreciation among student teachers at the Faculty of Art Education. Master Thesis, College of Art Education, Helwan University.

- El-Tanawy,E. (2002). Teaching and learning methods and their applications in educational research. Anglo-Egyptian, Cairo. 
- Ibrahim,U. (2015). The effect of the mind maps strategy in teaching metal works on developing academic achievement and decision-making skills for student teachers of the Art Education Department at the Faculty of Specific Education Assuit University. Journal of the Faculty of Education, 31(4).

- Ishaq,H. (2005).Aesthetics of histological formation in modern artistic trend. Journal of Educational Sciences, Research and Studies of the College of Education, Qatar University, Issue 8.

- Ismail,M. (2015). Statistics and Statistical Analysis using SPSS, Part One. Abu Hilal House for Printing and Publishing.

- Ismail,M. (2016a). Statistics and statistical analysis using SPSS, Part Two. Best Print Press.

- Ismail,M. (2016b). The Curriculum. Best Print Press.

- Saad Al-Din,L. (2010). The effectiveness of two patterns of providing maps of algebraic concepts in achievement and the development of mathematical thinking among first-graders in the Department of Mathematics. Journal of Research in the College of Basic Education, 9 (3), 115 -139.

- Terase, R.(2005).Teaching Real making. Journal Articles,58(2), Pp.40-45.

- Wilts,V. (2002).The Effect of concept maps and learning stylish seventh eradars learning geography. Dissertation Abstract International,.63(8).

- Zaitoun,H. (2003). Teaching Thinking - An Applied Vision in Developing Thinking Minds. Cairo: The World of Books.

- http://www.Aljazirah.com/culture/2008/07042008/tachke133.ht $\underline{\mathrm{m}}$

- http://www.mafhoum.com/press4/126c33.htm

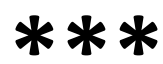

